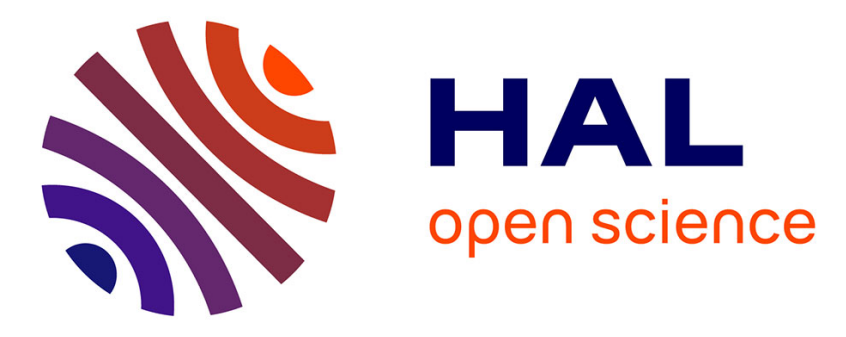

\title{
Does the VHP Sugar Price Influence in the Ethanol Volume Production?
}

Edison Sotolani Claudino, João Reis, Pedro Costa Neto, Antônio Lopes, Alessandra Q. Silva

\section{- To cite this version:}

Edison Sotolani Claudino, João Reis, Pedro Costa Neto, Antônio Lopes, Alessandra Q. Silva. Does the VHP Sugar Price Influence in the Ethanol Volume Production?. IFIP International Conference on Advances in Production Management Systems (APMS), Sep 2016, Iguassu Falls, Brazil. pp.579-586, 10.1007/978-3-319-51133-7_69 . hal-01615718

\section{HAL Id: hal-01615718 \\ https://inria.hal.science/hal-01615718}

Submitted on 12 Oct 2017

HAL is a multi-disciplinary open access archive for the deposit and dissemination of scientific research documents, whether they are published or not. The documents may come from teaching and research institutions in France or abroad, or from public or private research centers.
L'archive ouverte pluridisciplinaire HAL, est destinée au dépôt et à la diffusion de documents scientifiques de niveau recherche, publiés ou non, émanant des établissements d'enseignement et de recherche français ou étrangers, des laboratoires publics ou privés. 


\title{
Does the VHP Sugar Price Influence in the Ethanol Volume Production?
}

\author{
Edison Sotolani Claudino ${ }^{1}$, João Gilberto Mendes dos Reis ${ }^{1,2}$, Pedro L. O. \\ Costa Neto ${ }^{2}$, Antônio C. V. Lopes ${ }^{1}$, and Alessandra Q. Silva ${ }^{1}$ \\ 1 Federal University of Grande Dourados, Dourados, Brazil \\ 2 Paulista University, São Paulo, Brazil \\ edisonclaudino@ufgd.edu.br; betomendesreis@msn.com
}

\begin{abstract}
Brazil has become one of the major producers of sugar and ethanol. However, as both products share the same production process, the volume of production of sugar or ethanol is influenced by government policies and marketing prices. The purpose of this research is to analyze the influence of the international prices of VHP sugar in the mix of production of hydrous ethanol and sugar. A multiple linear regression studies with statistical software $\mathrm{R}$ was conducted using as reference data of Mato Grosso do Sul state, Brazil between 2002/03 and 2014/15. The results indicated that the sugar and ethanol production in this state was bonded to the prices variance of VHP sugar on the international market.
\end{abstract}

Keywords: sugarcane-ethanol production, marketing price, producion responsiveness.

\section{Introduction}

The agro-industrial production of sugarcane-ethanol has emerged as one of the most important sectors in developing countries due to its capability to produce food and clean energy. Brazil, for instance, has become the greatest producer and exporter of sugar worldwide. Since the 1970s the country has responded to an average of $45 \%$ of the world's exportations [1]. Moreover is a pioneer on ethanol production as a vehicular fuel [2] using a blender with gasoline (25\% ethanol anhydrous and $75 \%$ gasoline) and pure (hydrous ethanol) [3]. Thus, the internal demand of the product makes the fuel sector represents $1.5 \%$ of the Brazilian GDP [4]. However, despite these numbers, the production of different products at the same agriculture process has occasioned price floating and uncertainty related to the supply of both sugar and ethanol, which are the most produced items of the sugarcane supply chains [4].

This integrated production system was chosen because during the 1970s, with the world oil crisis and with the creation of the "Proalcool" program, and the urgency of ethanol production expansion, it made sense to annex to the existent sugarcane mills [5]. However, 40 years later, this decision has still affected the responsiveness of the supply chain in meeting the demands of both markets. 
When the Proalcool program started the National Petroleum Council, a Brazilian government agency created in 1938, ensured parity prices between anhydrous ethanol (blended with gasoline), hydrous ethanol and sugar [6]. Moreover, consumers were stimulated to use hydrous ethanol by setting the price at $64,5 \%$ of gasoline [7]. During the middle of the $1980 \mathrm{~s}, 90 \%$ of light duty vehicles were moved by ethanol fuel [8]. However, the decline in oil prices and the end of military government reduce drastically the production and use of ethanol as fuel [9]. Only in 2003, the ethanol started to be used as fuel largely again due to flex-fuel technology that allows cars to run with any blend combination of ethanol and gasoline [7].

Nowadays, the production of such commodities not always is bonded to the prices, once factors with previous contracts and the level of sugars present in the harvested canes are relevant aspects taken into consideration by the plants' directors. Such recoverable sugar (also known as Total Recoverable Sugar/TRS) is measured during the deliverance of sugarcane to the plants. This TRS measure has basically two purposes: (i) to estimate the amount of sugar that can be produced and (ii) to establish the value to be paid by the supplier.

In an overall view, the existence of this system makes that Brazil sugarcane agro-industry preferably concentrates its production on sugar (more profitable), what makes the ethanol a secondary product in this process. Nonetheless, the increase of the flex fuel cars and the current eco-friend pressures for the clean energy creation has resulted in an increase in ethanol demand and forced mills to reconfigure its priorities $[1,5]$.

The aim of this paper is to find empirical evidence if the variable of sugar price in the international market really contributes to explain the formation of the production mix (sugar and ethanol) and Brazilian sugarcane-ethanol Agroindustry. With this regard, we opted by a multiple linear regression analysis, which comprised three variables: (i) sugar production, (ii) hydrous ethanol production and (iii) price of VHP sugar for exportation/crop. The data were collected between 2002 and 2014 and Mato Grosso do Sul (MS) state was chosen as referential. We tested statically the hypothesis that VHP sugar price affects the mix of production in sugar-ethanol complex.

\section{Methodology}

To understand the responsiveness of Brazilian sugarcane-ethanol agro-industry this research focused on which factors have influenced throughout the last 13 crops the MS production of sugar, in relation to the destination of the sugarcane syrup for ethanol production. It is about a long and important period in which it is possible to measure the process of sugarcane production expansion after 2006 when a strong regional expansion of this sector was registered.

All data were analyzed using multiple linear regression technique [10] and calculated with statistical R software. According to Guo et al. the multiple linear regression model can be expressed in matrix notation by [10]: 


$$
\gamma=\chi \beta+\xi
$$

Where, $\gamma=$ is the vector which contains the dependent variables (sugar production); $\chi=$ is a matrix which contains both $\mathrm{k}$ variable values either regressor or independent (fixed value); $\beta=$ is the vector which corresponds to the regression coefficients bonded to the independent variables; $\xi=$ is the vector of order of random non-correlated errors with multi-varied normal distribution with zero average vector and common variance (homogeneous variances).

The multiple linear regression technique comprises the dependent and independent variables. In this study, the dependent variable was the sugar production in tons $(\mathrm{t})$ and the hydrous alcohol production $\left(\mathrm{m}^{3}\right)$, both obtained from the BIOSUL (Association of bioenergy producers from Mato Grosso do Sul state). The independent variable consisted on the series of prices of Very High Polarized (VHP) sugar for exportation furnished by CEPEA/ESALQ (Center of Advanced Studies in Applied Economy/ Superior School of Agriculture Luiz de Queiroz). To obtain the VHP sugar price, we used the month average between May to March (official date of center/south region crops) that comprises nearly the whole crops harvests and processing from MS state. The values were estimated in US dollars.

\section{Results}

In our study, we proposed a multiple regression to better establish the presented evidence that the sugar production (variant $\gamma$ ) may be explained by the prices of the VHP sugar on the international market and the hydrous ethanol production. We normalized the experimental errors from the result of the Shapiro-Wilk $(\mathrm{W}=0.9276$ e $\rho$-value $=0.3172)$ test. However, the Durbin-Watson test for the original data seemed to be significant for indicating the correlation among the residuals. In order to solve this problem, we applied the logarithmic transformation, proportioned by the exponential model $(\operatorname{Ln}(\gamma))$ and, posteriorly, the test confirmed the independence of the errors ( $\mathrm{DW}=1.7583$ and $\rho$-value $=0.163$ ). Table 1 presents the analysis of variance of the regression.

Table 1. Analysis of variance of the regression

\begin{tabular}{llllll}
\hline Source of variation & GL & SQ & QM & F & $\rho$-value \\
\hline Regression & 2 & 4.578905084 & 2.289452542 & 121.4182048 & $9.67836 \times 10-8$ \\
Residual (Error) & 10 & 0.188559248 & 0.018855925 & & \\
Total & 12 & 4.767464332 & & & \\
\hline
\end{tabular}

As we can see, test $\mathrm{F}$ showed a significant multiple linear regression, in other words, the sugar production may be explained by the price of sugar in the international market either for the hydrous ethanol production or for both produc- 
tions. Table 2 shows the averages of regression parameters through the method of least squares.

Table 2. Estimation of the regression parameters

\begin{tabular}{lllll}
\hline Variables & Parameters & Std Error & T Statistic & $\rho$-value \\
\hline Intercept & 12.34000 & 0.09815 & 125,747 & $<2 x 10-16$ \\
Sugar price $\left(x_{1}\right)$ & 0.04068 & 0.01047 & 43.885 & 0.003036 \\
Ethanol Production $\left(x_{2}\right)$ & $6.989 x 10-7$ & $1.153 x 10-7$ & 6.062 & 0.000122 \\
\hline
\end{tabular}

We observe by the $\rho$-value that both coefficients are not null to the significant level of $1 \%$. Thus, based on the variance of prices, the proposed model is able to attract the reality of the local sugar production $\left(R^{2}=0.9604\right)$. We conclude that the sugar production from the last 13 crops is strongly influenced by the variation of price of the VHP sugar in the international market and by the increase of the hydrous ethanol production. The model that better fits into the data may be described by the following equation:

$$
\ln (\gamma)=12.3400+0.04068 x_{1}+6.989 \times 10^{-7} x_{2}
$$

Where $\gamma$ corresponds to sugar production $(\mathrm{t}) ; x_{1}$ price of VHP sugar (US dollars); $x_{2}$ hydrous ethanol production $\left(\mathrm{m}^{3}\right)$. It worth mentioning that equation 2 refers to the $\ln (\gamma)$, not to the original variant itself. Thus, when we analyze the results, under the perspective of the problem, we must apply the inverse operation, we mean, reuse the unities of the original values from the model $\gamma k e^{k^{\prime} x_{1}} e^{k^{\prime \prime} x_{2}}\left(k, k^{\prime}\right.$ and $k^{\prime \prime}$ are constant estimated by least squares or maximum likelihood).

Our results allowed to observe that the behavior of the regional production of sugar is elastic to the positive variation of the international quotation of the VHP sugar. This result expresses that the regional sugar plants direct their production mix and the destination of the TRS based on the international prices, even if the production flows seem to be unfavorable, once there is no appropriated logistic infrastructure and the distance to the ports is very long.

There are evidenced of a good capacity of response of the sugarcane chain on the destination of the TRS to more profitable markets, even if the decision of production mix being taken differently every crop. Another factor that corroborated for the strategy of productive chain's responsiveness is that the plants have the option of working with the future deliverance of sugar. This mechanism enables the plants to stock the product throughout the crop and to execute their contracts only when the market is favorable, thus, they capture the value in the spot market of ethanol (anhydrous or hydrous), in other words, there is available commercialization throughout the crop. 


\section{Discussion}

\subsection{TRS and the Location of Production}

The sugar and ethanol productions' trade-off from the Total Recoverable Sugar values requires the verification of plants both technical and economic possibilities for the determination of which commodity will be more/less concomitantly produced.

The plants often have previously defined both the total volume of sugarcane to be processed during crop period (around six or seven months) and a daily capacity of sugar and ethanol, thus, it is not feasible to concentrate the production in a single commodity, because they run the risk of having extra mature cane to be cut. For this reason, the operational conditions force the mixed plants owners to produce simultaneously sugar and ethanol [11].

Mato Grosso do Sul state presents the lowest yield when compared to other states of the region, but if we analyze the local production, the new agricultural enterprises also brought some innovations and other varieties of cane (which are already in process of adaptation) consolidated in other Brazilian regions for a long period.

Salgado Júnior assures that the plants' efficiency also depends on the variable "localization". For example, São Paulo state presents the edaphoclimatic conditions more favorable to the extraction of a cane with a higher tenor of saccharose, which, consequently, may influence the operational efficiency of sugarcane plants [12]. In Figure 1, we compare the variance of TRS yields of the crops from $2002 / 03$ to $2014 / 15$ by state.

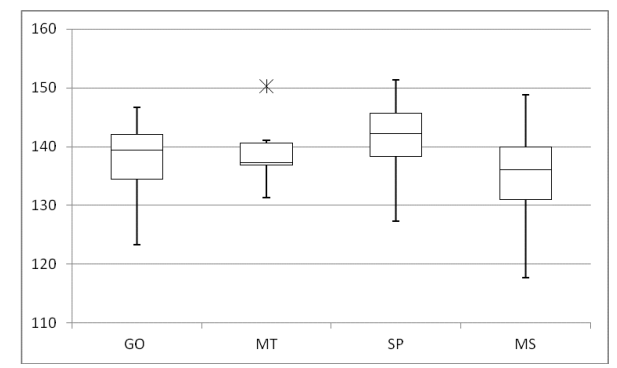

Fig. 1. Box plot graphic of the average TRS between SP and the states of Goiás (GO), Mato Grosso (MT) and Mato Grosso do Sul (MS).

The important combination for the development of the cane in São Paulo region resulted from the good soil conditions, better infrastructure of energy and transportation, proximity to bigger markets and, above all this, a regional system of innovation that comprises producers, capital goods industries, research institutes and universities [13]. 
The expansion process of sugarcane is a result from the new expansion routes, especially from the advance of new agricultural frontiers, like the Midwest states and Minas Gerais. This movement results from the great availability of farmable lands, with adequate topographic conditions to the mechanization and edaphoclimatic characteristics favorable to sugarcane cultivation [14].

This way, it is possible to infer that even TRS is an important factor that determines the production mix, the sugarcane-ethanol agro-industries have opted for regions with low prices of lands and high fiscal incentives, despite the low TRS yields [14].

\subsection{Ethanol and Sugar Responsiveness}

The factor that directs the ethanol production is bonded to the price policies for fossil fuel adopted in Brazil. Hydrous ethanol presents $70 \%$ of price limit for consumers in relation to gasoline and cannot be readjusted due to the increase in prices over the last years. The increase in costs is due mainly to factors like the high tax burden, strong valorization of the current currency, precarious infrastructure of the production flow, inter alia [15].

Considering the financial ceiling's limit of $70 \%$ of the gasoline at the pump, Figure 2 presents ethanol how ethanol has lost competitiveness over the years in comparison with the gasoline in Brazil, even in São Paulo state, which is the biggest national consumer.

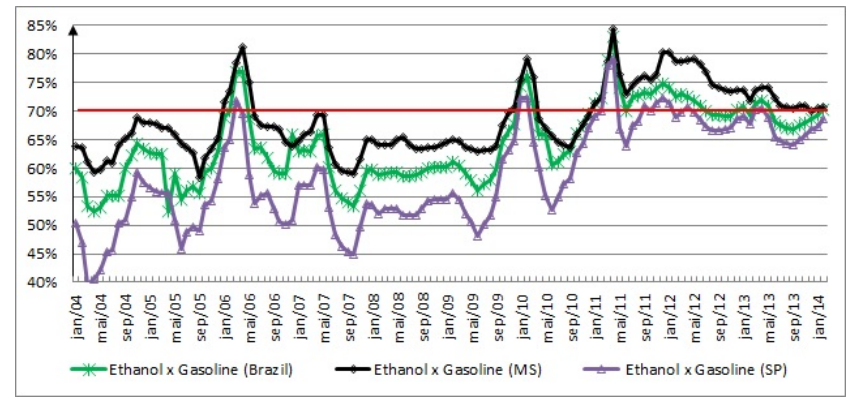

Fig. 2. Comparison Chart of parity between gasoline and ethanol

São Paulo state has historically shown the most competitive biofuel taxes of the country with respect to gasoline, especially due to its privileged geographic position close to consumers from urban centers and due to the fact that there have been for a long time good operational and logistic conditions favorable to production and distribution of ethanol [16].

In Mato Grosso do Sul state, the parity ethanol versus gasoline is less competitive when compared to São Paulo state, which follows the national average. Thus, we observe the normal market variations (seasonality), although is evident the strong political influence over the fuel prices. 
In relation to sugar responsiveness a good alternative for compensating the low prices of ethanol is to direct part of the TRS production mix to sugar. Through this option, the plants have higher flexibility and capacity of market response in order to maximize their profitability and to reduce the market risks. Figure 3 compares the production of ethanol and sugar in Mato Grosso do Sul state during the crops of $2002 / 03$ to $2014 / 15$.

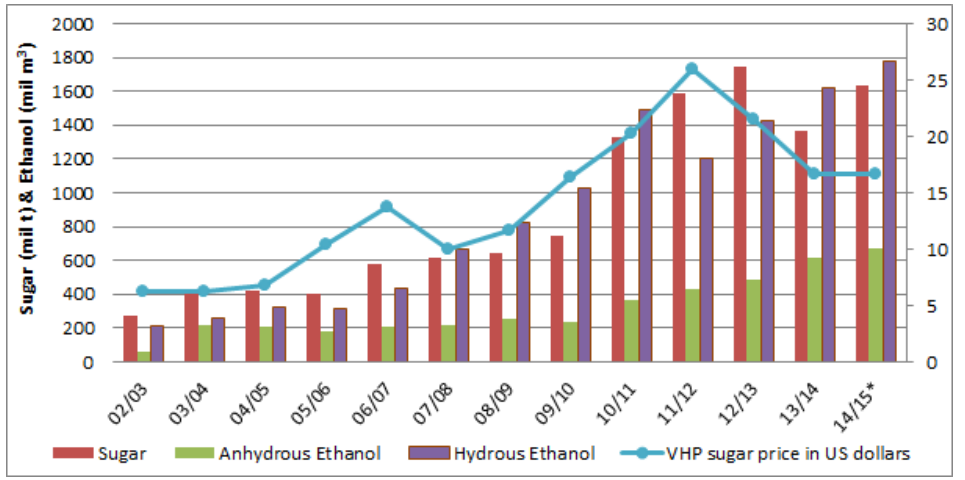

Fig. 3. Evolution of the ethanol and sugar productions in MS state and sugar prices

The evolution of crop series used in this study showed a slight increase in the sugar prices in US dollar, whose peak was reached during the crop 2011/2012. Right after the peak, we observe a decrease due to the world production increase. This scenario is in accordance with the international market $[1,5]$.

The sugar and hydrous ethanol production in Mato Grosso do Sul state increased after the 2008/09 crop, mainly influenced by the expansion of the activity in the state. Thus, it is possible to verify that the anhydrous ethanol production, in spite of a progressive increase in the last crops, still can be considered as residual in the regional plants. This reflects the challenge of the market in establishing to ethanol a competitive price along the year, by evidencing the influence of sugar in ethanol productivity and competitiveness [2]. Finally, we can conclude that sugar plays a predominant role in the decision of the production mix.

\section{Conclusions}

The data analysis enabled us to identify the evidence related to external factors, which interfere the decision makers during the process of directing the production. We verified that the regional sugar production during the crops of 2002/03 to $2014 / 15$ was bonded to the price variance of VHP sugar in the international market.

The analysis of responsiveness of TRS, using the multiple regression model, indicated that the sugarcane supply chain in Mato Grosso do Sul state change 
its production mix to the more profitable markets, although the decisions are taken every 12 months, what corresponds to each crop.

In Further studies we intent analysis the responsiveness of sugarcane supply chain in Brazil to confirm the influence of VHP price in ethanol volume production showed in Mato Grosso do Sul state.

\section{References}

1. Pop, L.N., Rovinaru, M., Rovinaru, F.: The Challenges of Sugar Market: An Assessment from the Price Volatility Perspective and its Implications for Romania. Procedia Econ. Finance 5, 605-614 (2013)

2. Hira, A.: Sugar Rush: Prospects for a Global Ethanol Market. Energy Policy 39(11), 6925-6935 (2011)

3. Cavalcanti, M., Szklo, A., Machado, G.: Do Ethanol Prices in Brazil Follow Brent Price and International Gasoline Price Parity? Renew. Energy 43, 423-433 (2012)

4. Du, X., Carriquiry, M.A.: Flex-fuel Vehicle Adoption and Dynamics of Ethanol Prices: Lessons from Brazil. Energy Policy 59, 507-512 (2013)

5. Dias, M.O.S., Maciel Filho, R., Mantelatto, P.E., Cavalett, O., Rossell, C.E.V., Bonomi, A., Leal, M.R.L.V.: Sugarcane Processing for Ethanol and Sugar in Brazil. Environ. Dev. 15, 35-51 (2015)

6. Rico, J.A.P., Mercedes, S.S., Sauer, I.L.: Genesis and Consolidation of the Brazilian Bioethanol: A Review of Policies and Incentive Mechanisms. Renew. Sustain. Energy Rev. 14(7), 1874-1887 (2010)

7. Stattman, S.L., Hospes, O., Mol, A.P.: Governing Biofuels in Brazil: A Comparison of Ethanol and Biodiesel Policies. Energy Policy 61, 22-30 (2013)

8. Puppim de Oliveira, J.: The Policymaking Process for Creating Competitive Assets for the use of Biomass Energy: the Brazilian Alcohol Programme. Renew. and Sustain. Energy Rev. 6(1-2), 129-140 (2002)

9. Lehtonen, M.: Social Sustainability of the Brazilian Bioethanol: Power Relations in a Centre-periphery Perspective. Model. Environ. Econ. Soc. Asp. Assess. Biofuels 35(6), 2425-2434 (2011)

10. Guo, G., You, W., Qian, G., Shao, W.: Parallel Maximum Likelihood Estimator for Multiple Linear Regression Models. J. Comput. Appl. Math. 273, 251-263 (2015)

11. Valente, M.S., Nyko, D., Reis, B.L.S.F.S., Milanez, A.Y.: Bens de Capital para o Setor Sucroenergético: A Indústria está Preparada para Atender Adequadamente a Novo Ciclo de Investimentos em Usinas de Cana-de-açúcar? BNDES Setorial 1(13), 119-178 (2012)

12. Salgado Junior, A.P., Carlucci, F.V., Novi, J.C.: Aplicação da Análise Envoltória de Dados (AED) na Avaliação da Eficiência Operacional Relativa entre Usinas de Cana-de-açúcar no Território Brasileiro. Eng. Agríc. 34(5), 826 - 843 (2014)

13. Furtado, A.T., Scandiffio, M.I.G., Cortez, L.A.B.: The Brazilian Sugarcane Innovation System. Energy Policy 39(1), 156-166 (2011)

14. Milanez, A.Y., Nyko, D., Garcia, J.L.F., Xavier, C.E.O.: Logística para o Etanol: Situação Atual e Desafios Futuros. BNDES Setorial 1, 49-98 (2010)

15. Regazzini, L.C., Bacha, C.J.C.: A tributação no Setor Sucroenergético do Estado de São Paulo: Anos de 2000 e 2008. Rev. Econ. e Sociol. Rural 50(4), 801-818 (2012)

16. Costa, C.C., Guilhoto, J.J.M.: O Papel da Tributação Diferenciada dos Combustíveis no Desenvolvimento Econômico do Estado de São Paulo. Econ. Apl. 15(3), 369-390 (2011) 